\section{Metacognitive Transcendence in the Learning of the Project Activity of Design through the Sketchbook Visuality}

\begin{abstract}
This article aims to report the transition from intuitive to intentional projective activities in design recorded in the visual modes of sketchbook to analyze the metacognitive processes of design students. Phenomenography was used as an empirical sampling method to diagnose the sketchbooks of industrial design and graphic design students. The observation criteria focused on describing the metacognitive characteristics of the students with respect to the way they recorded their ideas visually, which showed design-specific projective actions. This research demonstrated and codified how students externalize intentional approaches in their sketchbook iterations, which can be grouped into three representation strategies: technical, methodological, and reflective; they are related to their experiences in projective activity. Consequently, we propose a new category called metacognitive transcendence, which refers to a strategy for controlling and regulating cognitive processes to transform an intuitive action into an intentional action mediated by a cognitive artifact: the design sketchbook. Three ways of metacognitive transcendence are suggested: instrumental (technical aspects), procedural (related to projection), and comprehensive (own reflection about the project itself).
\end{abstract}

Diego Aníbal Restrepo-Quevedo Post-doctorate in Education, Social Sciences, and Interculturality; Design and Creation PhD.

Associate Professor, Universidad de Bogotá Jorge Tadeo Lozano, Bogotá, Colombia. Email: diego.restrepoq@utadeo.edu.co 두 orcid.org/0000-0001-5649-6429

Google Scholar

Juanita González Tobón Ph.D. (c) in Design and Creation. Assistant Professor, Pontificia Universidad Javeriana. Bogotá, Colombia. Email: gonzalez-juanita@javeriana.edu.co (-) orcid.org/0000-0002-6079-9024 Google Scholar

\section{Roberto Cuervo}

Ph.D. in Design and Creation.

Associate Professor, Pontificia Universidad Javeriana, Bogotá, Colombia.

Email: rcuervo@javeriana.edu.co

(1) orcid.org/0000-0003-4624-0678

Google Scholar

Jorge Camacho

M.Sc. in Education.

Assistant Professor, Pontificia Universidad Javeriana, Bogotá, Colombia.

Email: j-camacho@javeriana.edu.co (1) orcid.org/0000-0003-1357-4858

Google Scholar

Edgar Hernández-Mihajlovic M.Sc. in Education.

Assistant Professor, Pontificia Universidad Javeriana, Bogotá, Colombia.

Email: edgar.hernandez@javeriana.edu.co ๑ orcid.org/0000-0003-1692-741X

Google Scholar

Received: April 14, 2021

Approved: August 20, 2021

Key words:

Design, learning, sketchbook, metacognition, visual. 


\section{La trascendencia metacognitiva en el aprendizaje de la actividad proyectiva del diseño a través de la visualidad de la bitácora}

\section{Resumen}

Este artículo tiene como objetivo reportar el tránsito de las actividades proyectivas intuitivas a las intencionadas en el campo del diseño que son registradas en los modos visuales de la bitácora, con el propósito de analizar los procesos metacognitivos de estudiantes de diseño. Se utilizó la fenomenografía como método para realizar un muestreo empírico para el diagnóstico de bitácoras de estudiantes de diseño industrial y diseño gráfico; los criterios definidos para la observación se centraron en describir las características metacognitivas de los estudiantes en las maneras de registrar visualmente sus ideas, en las que se identificaron acciones proyectivas propias del diseño. Como resultado de esta investigación se pudo evidenciar y codificar la forma como los estudiantes en sus iteraciones en la bitácora externalizan enfoques intencionados que pueden agruparse en tres estrategias de representación: técnicas, metodológicas y reflexivas, todas estas relacionadas con sus experiencias en la actividad proyectiva. En consecuencia, se propone una nueva categoría que se ha denominado trascendencia metacognitiva, entendida como una estrategia de control y regulación de los procesos cognitivos para transformar una acción intuitiva en una acción intencionada con intermediación de un artefacto cognitivo, que para este estudio fue la bitácora de diseño. Se exponen tres formas de trascender metacognitivamente: una instrumental, referida a lo técnico; otra procedimental, referida a la forma en la que se proyecta; y una comprensiva, referida a la reflexión sobre el proyecto mismo.
Palabras clave:

diseño, aprendizaje, bitácora, metacognición, visual. 


\section{Introduction}

This article aims to discuss the relevant metacognitive processes industrial design and graphic design students incorporate, as noted in the visual modes (Anstey \& Bull, 2010; Restrepo-Quevedo, 2015) present in their sketchbook, understood as those modes that externalize mental models graphically. Design tends to be taught by projects that seek to transform poorly structured situations (Simon, 1973) into preferable ones (Simon, 1996); therefore, the student is expected to learn to design by designing. This research reflects upon the sketchbook influence on the metacognitive processes that perfect a design project.

The concept of metacognition associated with Flavell $(1976,1979)$ since its inception (Livingston, 2003) identifies two components. The first one, related to metacognitive knowledge (Flavell, 1979), refers to the beliefs or conceptions of the subject about factors or variables in people, tasks, and strategies act or interact to accomplish a cognitive objective to regulate them. The second one involves metacognitive experiences (Flavell, 1979), defined as the ways of experiencing a reality or process in a cognitive activity, which generally manifests itself in regulating the process. Therefore, these processes help regulate and monitor learning and are associated with the planning, monitoring, and testing of cognitive activities. From this perspective, cognitive activities are the objective the student pursues, while metacognitive activities are related to how the student defines an adequate strategy for transforming an intuitive action into an intentional one.

Design recognizes the importance of studying the discipline from a metacognitive viewpoint (Ball \& Christensen, 2019); so, authors such as Carlson et al. (2020) have attempted to understand its operation in order to 
identify those characteristics that are effective in a strategy when approaching a design process.

Other authors (Kavousi et al., 2020) propose a metacognition model based on the design activity. It integrates three approaches that refer to categories of thought in metacognitive design: reflective control processes —regulating situations, environment, and feelings—, reflective knowledge processes making sense of how design occurs - , and reflective monitoring processes judgments that students make about their learning status-.

The concept of reflection should refer to the ability of the students to carry out an introspective-projective process whose aim is to identify, in terms of Flavell (1979), steps and experiences to determine successful strategies for tackling a given problem in their learning process. We emphasize how metacognitive processes should be part of design learning practices to guarantee that the projective activity takes place based on the knowledge and experiences appropriated by the students after the reflective mental processes underlying the creation and development of design products. Powers (2016) states that providing design students with instruction and feedback on their cognitive processes should be considered an essential characteristic of design teaching.

According to the approaches above, the process reported in this paper accounts for our interest in knowing how some of the students' cognitive and metacognitive processes operate through the visual modes recorded in their sketchbooks. Therefore, we asked ourselves about the characterizations of these processes during the projective activity. Following a modified phenomenography approach, this report then presents the adaptive ways of taking advantage of design students' knowledge and experiences for metacognitive purposes. 
In design theory, the idea of the projective activity arises from the notion of design action that focuses the cognitive process on three activities: problem statement, problem solving, and strategy definition (Cross, 2006; RestrepoQuevedo, 2016; Visser, 2006a). Therefore, we use the etymological meaning of the activity concept to assign multiple actions to achieve a result as the planning process, the projective concept as the students' ability to see beyond or trigger a situation to achieve a result, and finally, design as the knowledge domain from which this study emerges.

\section{Metacognition in Design Learning}

Metacognition is a powerful field of study for improving educational practice (Livingston, 2003; Mayer, 1998; Yzerbyt et al., 1998). Its potential lies in the student's reflective opportunities during his or her development and how they are seized throughout a teaching and learning process. Reflection allows students to refine, control, and decide strategies that guarantee adaptation to the educational contexts to which they belong.

For Powers (2016), metacognition in design is a way of regulating cognitive processes and strategies for learning and can be worked in the classroom as "a supervisor or trainer of cognitive processes; a key determinant in using design strategies; and one of the most critical factors in proactive engagement and self-regulated learning" (p. 74). In this research, the interest lies in understanding how metacognition helps students to monitor and improve their cognitive processes while designing, specifically when they face a poorly structured problem (Simon, 1973), using projective activity strategically. This activity takes shape in mental and externalization processes noted in the visual modes (Jewitt, 2011) present in the sketchbook. 
For metacognition to contribute to resolving poorly structured problems (Simon, 1973; Visser, 2006a) in design learning, students require two conditions: on the one hand, knowledge of design strategies and, on the other hand, the intentional follow-up of their design learning (Powers, 2016). However, educational processes in design often focus on teaching design strategies and methods and measure students' learning by the results they achieve with their projects, leaving aside the importance for the student to "understand the value of self-observation and how to do it during studio" (Powers, 2016, p. 73).

Concerning the metacognitive phenomena of design didactics, our motivation is to recognize it as a fundamental skill to promote projective activity learning since "metacognitive processes are designed to optimize one's cognitive actions in pursuit of learning goals" (Griffin et al., 2013, p. 20) by contributing to knowledge acquisition, retention, understanding, and application (Tamayo, 2006).

Metacognition initially focuses on developing skills based on previous experiences; that is, it orchestrates the possibility to bring together transmitted knowledge and a lived experience, discovering ways to further develop and optimize cognitive strategies based on a desirable result.

As Yzerbyt et al. (1998) stated, the chief conceptual difficulty of metacognition is its conscious capacity, so we prefer to use the expression "intentioned". Meanwhile, most of the cognitive processes are unconscious, so we will employ the term "intuitive". Their study is based on a student's decision about a metacognitive phenomenon that has not necessarily been observed during their construction of a mental model (Norman, 1991), nor in their knowledge experience. It is then a new process of the student, who integrates these conditions into their learning. 


\section{Intuitive and Intentional Projective Activity}

In the context of this research, we understand projective activity as those actions performed during the design process that are mainly related to the specific didactics of design. Consequently, the projective action is any design operation that transforms an imbalance into a preferable situation (Simon, 1996) mediated by artifacts (Krippendorff, 2007).

Design thinking (Brown \& Martin, 2015; Burnette, 2009) and the theoretical constructions of design cognition (Cross, 2001; Visser, 2006a) focus on describing projective activity for transformation purposes, its steps, and specific stages. Comprehending how we think and learn during design operations is directly related to how poorly structured situations are approached (Simon, 1973; Visser, 2006b). Therefore, the problem category triggers projective activity and undertakes it by emphasizing aspects that reveal its characterization for appropriate problem statement.

We recognize the importance of linking metacognition to the projective design activity to understand how students select and deploy strategies to navigate through a context of uncertainty in problems defined by the theory as "wicked" (Buchanan, 1992; Rittel \& Webber, 1973) using strategies adjusted to the assignment of tasks on the projective activity timeline.

Metacognition enables the designer to recognize how to move between intuitive and intentional actions for decision-making in response to the fluctuation of problem statement and the inference of uncertainty (Ackerman \& Thompson, 2017). Thus, a project becomes the educational setting to bring students closer to design learning, which confronts them with the problems described above so that they deal with uncertainty as the core of design thinking (Dorst, 2011). 
From the projective activity, a project derives in design ways (Cross, 2006) of seeking a preferable result (Simon, 1996) according to the specialty.

Therefore, students need to have regulation strategies for their cognitive processes in design learning to move between intuitive and intentional actions mediated by cognitive artifacts (Norman, 1991; Visser, 2006b), materialized in the design sketchbook for this research. In the learning process of projective activity, teachers can help students move between the two systems of the dual process that Epstein (2010) conceives as the Cognitive-Experiential Self-theory (CEST): the intuitive/experiential system and the rational/analytical system.

In projective activity, this uncertainty causes students to automatically activate the experiential/intuitive system, which is closely linked to the necessary characteristics of the generation and ideation stages recorded in the sketchbooks. The student starts from experience, imagination, and visualization to project using tacit, non-verbal, or linear elements and goes through complex association and problem-solving processes.

However, when delimiting the design project in a learning process, the intuitive characteristics described above must be brought into the rational/analytical system to specify fundamental aspects of both the project and design learning, which is noticed in the student's internalization of a projective activity. So, it is important to observe and provide feedback on the intentional efforts of students materialized in their proposals. The means to do so are the metacognitive processes in design learning.

This research accesses the experiential/intuitive and rational/analytical cognitive systems based on Epstein's contributions (2010) to characterizing CEST principles and attributes to search for records in the sketchbooks that reveal the externalizations of these two systems (intuitive projective actions 
and intentional projective actions, respectively). In these projective actions typical of design, we can identify three forms of visual externalization: one in which qualities on technical aspects are appreciated at the graphic level; another one that exalts the methodological processes applied to the project; and one more that reveals the reflections on the project by the students and their learning processes. For this research, they were conceived as intuitive or intentional projective actions in relation to technical, methodological, or reflective processes recorded in the sketchbook.

\section{Research Method: Phenomenographic Approach}

In design learning processes, the sketchbook visuality (Ramírez, 2020) plays a fundamental role in the performance of the projective activity; however, this instrument is usually employed for sketching and taking notes on the progress of a project, rather than as a cognitive artifact mediated by externalization modes that can enhance design training (González-Tobón et al., 2020). Students also find stages of their learning in the sketchbook; hence, sketches become reflection material that enhance their control and regulation processes in the ideation stage. Based on this problem, we ask ourselves: What is the influence of the representations in the visual modes recorded in the sketchbook on learning projective activity and how is it related to design students' metacognitive processes?

This research had a modified phenomenographic approach to understand the metacognitive phenomenon and its characterization in design learning (Marton, 1986; Tight, 2016). It focuses on the qualitative and diverse ways of experiencing the use, interaction, and intervention of the knowledge of a discipline (González-Ugalde, 2014), which are later analyzed and compared with actions and results to explain the findings during the process. 
This methodological approach has its origins in research on learning approaches, identifying phenomenography as a research method to map the different qualitative ways in which people experience, conceptualize, perceive, and understand the world around them (Marton, 1986, p. 31).

A methodological design was created to recognize projective actions externalized and visually recorded in a sketchbook by design students when learning. It made it possible to detect how mental (Johnson-Laird, 1980) and conceptual (Norman, 1983) models transmitted by teachers are appropriated and internalized by students as metacognitive aspects of their learning, showing the cognitive transformation of intuitive actions into intended ones.

Empirical sampling was carried out to diagnose students' sketchbooks taking projective-type courses, selecting a sample of 25 industrial design and 23 graphic design sketchbooks. For convenience, we chose five design sketchbooks from each program that clearly showed the visual record of projective activity. The codification criteria were defined to identify intuitive and intentional projective activities of a technical, methodological, and reflective nature, visually externalized in the sketchbooks.

Table 1 shows the coding of the observed projective activities. Note the transition from intuitive to intentional activities of a technical, methodological, and reflective nature, with which we could analyze from a cognitive approach the emergence of three ways of transcending metacognitively: instrumental, procedural, and comprehensive. 
Table 1. Coding of Intuitive and Intentional Activities in Design Sketchbooks

\begin{tabular}{ccc}
\hline & \multicolumn{2}{c}{ Cognitive Transformation } \\
\hline $\begin{array}{c}\text { Approaches } \\
\text { Metacognitive }\end{array}$ & $\begin{array}{l}\text { Intuitive } \\
\text { Activity }\end{array}$ & $\begin{array}{c}\text { Intentional } \\
\text { Activity }\end{array}$ \\
Instrumental & Ins-Aiu & Ins-Aie \\
Procedural & Pro-Aiu & Pro-Aie \\
Comprehensive & Com-Aiu & Com-Aie \\
\hline
\end{tabular}

Note. The coding was based on the initials of the main categories but given the repetition of words, we took the letters that differentiate them.

Source: Own elaboration.

From Epstein's (2010) definitions of the principles and attributes of both the experiential/intuitive and rational/analytical systems (p. 299), Table 2 shows the transpositions to the field of design to shed light on the possible evidence found in the students' externalizations on their design sketchbooks. 
Table 2. Observation Criteria for Visual Records of Intuitive and Intentional Actions in Design Sketchbooks

\begin{tabular}{|c|c|c|c|}
\hline \multirow{2}{*}{$\begin{array}{l}\text { Epstein's Intuitive- } \\
\text { Experiential System }\end{array}$} & \multicolumn{2}{|c|}{ Projective Activities } & \multirow{2}{*}{$\begin{array}{l}\text { Epstein's Rational- } \\
\text { Analytical System }\end{array}$} \\
\hline & Intuitive Activity & Intentional Activity & \\
\hline \multirow{3}{*}{$\begin{array}{l}\text { Works by automatically } \\
\text { learning from experience } \\
\text { / Holistic }\end{array}$} & $\begin{array}{l}\text { Variety of combined } \\
\text { techniques (Ins-IuA) }\end{array}$ & $\begin{array}{l}\text { Drawing as a form of } \\
\text { externalization (Ins-IeA) }\end{array}$ & \multirow[t]{3}{*}{$\begin{array}{l}\text { Operates by conscious / } \\
\text { analytical reasoning }\end{array}$} \\
\hline & $\begin{array}{l}\text { Reiterated checking } \\
\text { mechanisms (Pro-IuA) }\end{array}$ & $\begin{array}{l}\text { Representation method } \\
\text { identified for a particular topic } \\
\text { (Pro-IeA) }\end{array}$ & \\
\hline & $\begin{array}{l}\text { Relates the sketch spatially } \\
\text { (Com-IuA) }\end{array}$ & $\begin{array}{l}\text { Relates the model to } \\
\text { experiential use (Com-IeA) }\end{array}$ & \\
\hline $\begin{array}{l}\text { Non-verbal: Encodes } \\
\text { information into images, } \\
\text { metaphors, settings, and } \\
\text { narratives. *In design, } \\
\text { this can be multimodal }\end{array}$ & $\begin{array}{l}\text { Technique experimentation } \\
\text { (Ins-IuA) } \\
\text { In design, it is about the } \\
\text { "intimate" non-verbal, } \\
\text { which helps think }\end{array}$ & $\begin{array}{l}\text { Materialization of a way to } \\
\text { externalize in a field (Ins-IeA) } \\
\text { In design, externalizations that } \\
\text { allow me to verbalize and } \\
\text { reflect with the other according } \\
\text { to the codes and meanings of } \\
\text { visual language }\end{array}$ & $\begin{array}{l}\text { Verbal: Encodes } \\
\text { information into abstract } \\
\text { symbols, words, and } \\
\text { numbers. }\end{array}$ \\
\hline $\begin{array}{l}\text { Effortless and minimally } \\
\text { demanding cognitive } \\
\text { resources }\end{array}$ & Object-related (Com-IuA) & $\begin{array}{l}\text { Relationship with the subject } \\
\text { (Com-IeA) }\end{array}$ & $\begin{array}{l}\text { Relatively strenuous and } \\
\text { demanding cognitive } \\
\text { resources }\end{array}$ \\
\hline $\begin{array}{l}\text { More crudely integrated: } \\
\text { Context specific; } \\
\text { organized by cognitive- } \\
\text { affective networks }\end{array}$ & $\begin{array}{l}\text { Thorough instruction } \\
\text { development (Pro-IuA) } \\
\text { Follows the teacher's } \\
\text { instructions } \\
\text { Discovery of perspective as } \\
\text { a way of representing (Pro- } \\
\text { IuA) }\end{array}$ & $\begin{array}{l}\text { Appropriate and internalized } \\
\text { instruction development (Pro- } \\
\text { IeA) } \\
\text { The isometric perspective to } \\
\text { understand functioning in } \\
\text { space (Pro-IeA) }\end{array}$ & $\begin{array}{l}\text { More highly integrated; } \\
\text { organized by general } \\
\text { principles of context }\end{array}$ \\
\hline $\begin{array}{l}\text { Evidently valid: } \\
\text { Experiment to believe }\end{array}$ & $\begin{array}{l}\text { Multiple views (Ins-IuA) } \\
\text { Experimental - Lower level } \\
\text { of argumentation }\end{array}$ & $\begin{array}{l}\text { Front and isometric view (Ins- } \\
\text { IeA) } \\
\text { Higher level of argumentation }\end{array}$ & $\begin{array}{l}\text { Requires justification by } \\
\text { logic and evidence }\end{array}$ \\
\hline Emotional & $\begin{array}{l}\text { Development of a form of } \\
\text { production whose value lies } \\
\text { in the meaning for the } \\
\text { subject, who is the author. } \\
\text { Personal resources built for } \\
\text { my own understanding and } \\
\text { the analysis of my own } \\
\text { procedure - self-analysis of } \\
\text { my proposal (Pro-IuA) }\end{array}$ & $\begin{array}{l}\text { "Rational" externalization that } \\
\text { acquires cultural and social } \\
\text { properties to adapt to the } \\
\text { symbols and meanings of a } \\
\text { disciplinary symbolic field of } \\
\text { design (Pro-IeA) }\end{array}$ & Free of affection \\
\hline $\begin{array}{l}\text { Motivated by the hedonic } \\
\text { principle to maximize } \\
\text { pleasure }\end{array}$ & $\begin{array}{l}\text { Unfinished satisfaction } \\
\text { with a search for pleasure } \\
\text { in the result (Com-IuA) }\end{array}$ & $\begin{array}{l}\text { Achieves the construction of a } \\
\text { preferable reality (Com-IeA) }\end{array}$ & $\begin{array}{l}\text { Motivated by the reality } \\
\text { principle to build a } \\
\text { coherent world model }\end{array}$ \\
\hline $\begin{array}{l}\text { Associative connections } \\
\text { between stimuli, } \\
\text { responses, and outputs }\end{array}$ & $\begin{array}{l}\text { Those responses and } \\
\text { connections that differ from } \\
\text { the teacher's conceptual } \\
\text { model and are specific to } \\
\text { the student (Com-luA) } \\
\text { Referents }\end{array}$ & $\begin{array}{l}\text { Understanding the principles } \\
\text { (Com-IeA) } \\
\text { When a timeline appears, } \\
\text { relationshipp with use: the time } \\
\text { variable is added to space, and } \\
\text { it materializes. Sequence of } \\
\text { use / Determinants and } \\
\text { requirements (Com-IeA) }\end{array}$ & $\begin{array}{l}\text { Cause-effect connections } \\
\text { between stimuli, } \\
\text { responses, and outputs }\end{array}$ \\
\hline
\end{tabular}

Note. Description of the criteria to identify visual records in the sketchbook based on the Intuitive-Experiential System and the Rational-Analytical System (Epstein, 2010).

Source: Own elaboration. 
Therefore, we used interpretive hermeneutics (Holroyd, 2009) to approach the data and contrast the design sketchbook as a cognitive artifact (GonzálezTobón et al., 2020), development proposals, and the process followed by the study participant from the coding of visual records in the sketchbook (Figure 1). Three exercises by three different students (the first and third from industrial design and the second from graphic design) denote transitions from intuitive projective activity to intentional projective activity and help track metacognitive aspects of design learning.

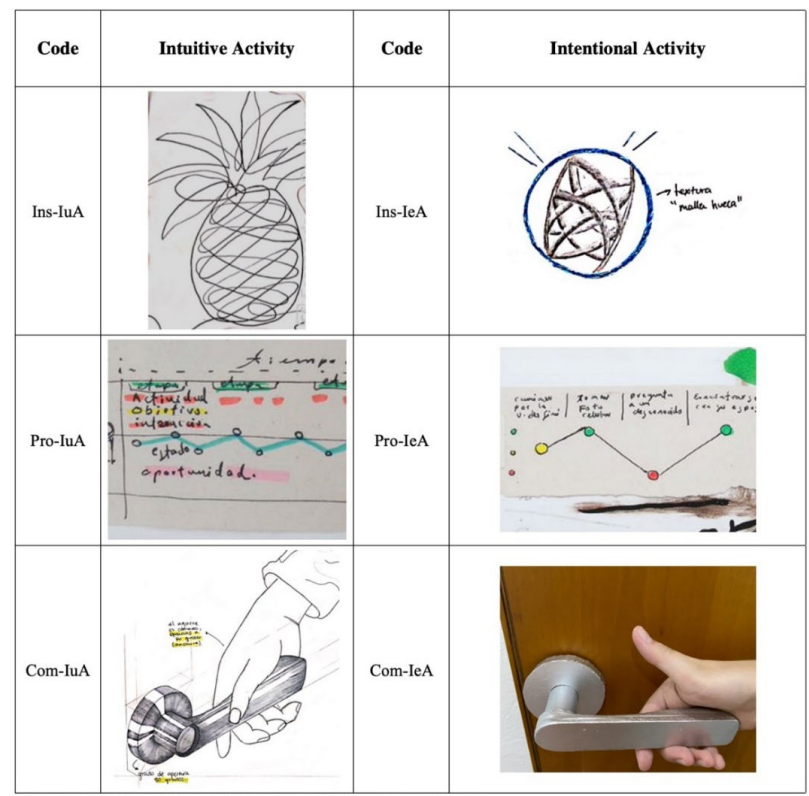

Figure 1. Evidence of coded visual records in the sketchbook. Note. The findings in the evidence are directly related to focusing the student's metacognitive effort on three projective actions (technical, methodological, and reflective) in intuitive and intentional activities. 
This method enabled us to encode the visual records in the studied sketchbooks to detect the students' technical, methodological, and reflective projective actions, both intuitive and intentional, which gave rise to the three categories of metacognitive transcendence that we have called instrumental, procedural, and comprehensive.

\section{Discussion: An Epistemology of Metacognitive Transcendence}

As discussed in the previous section, we understand the metacognitive process in design as the transition between a sequence characterized by an Intuitive Action (luA) followed by an Intentional Action (leA), related to the projective activities inherent to design disciplines.

This research could verify through our evidence how the metacognitive processes described in the literature (Flavell, 1976, 1979) —-metacognition of knowledge and metacognition of experience or regulation- expressly manifest in the projective activities that design students carry out. Figure 1 shows that this manifestation provides alternatives in which students establish a dialogue between cognitive and metacognitive processes through continuous iteration, adding internalized knowledge to each iteration.

The above refers to higher-order thinking, which implies active control over the cognitive processes associated with learning (Livingston, 2003). Our review identified how active control, in the case of design, focus on the student's autonomy to regulate their learning in different operations that characterize the design action, which we will call ways of transcending.

Transcendence is then the focus of students to construct meaning in depth (Smith \& Colby, 2007) on a process of the discipline itself, as noted in the transition from IuA to Ie $A$ in specific control tasks at a higher level. We determined how, 
while the student is experimenting through a necessary iteration process, his or her focus is on a learning activity. In this way, even if the student is repeatedly following the same procedure, his or her aim is not necessarily to achieve a specific result or find a solution to the challenge posed by the project. In our evidence, we could characterize three different ways of metacognitively transcending, which are presented in Table 3.

Table 3. Characterization of the Intuitive and Intentional Projective Activities of the Various Ways of Transcending Metacognitively

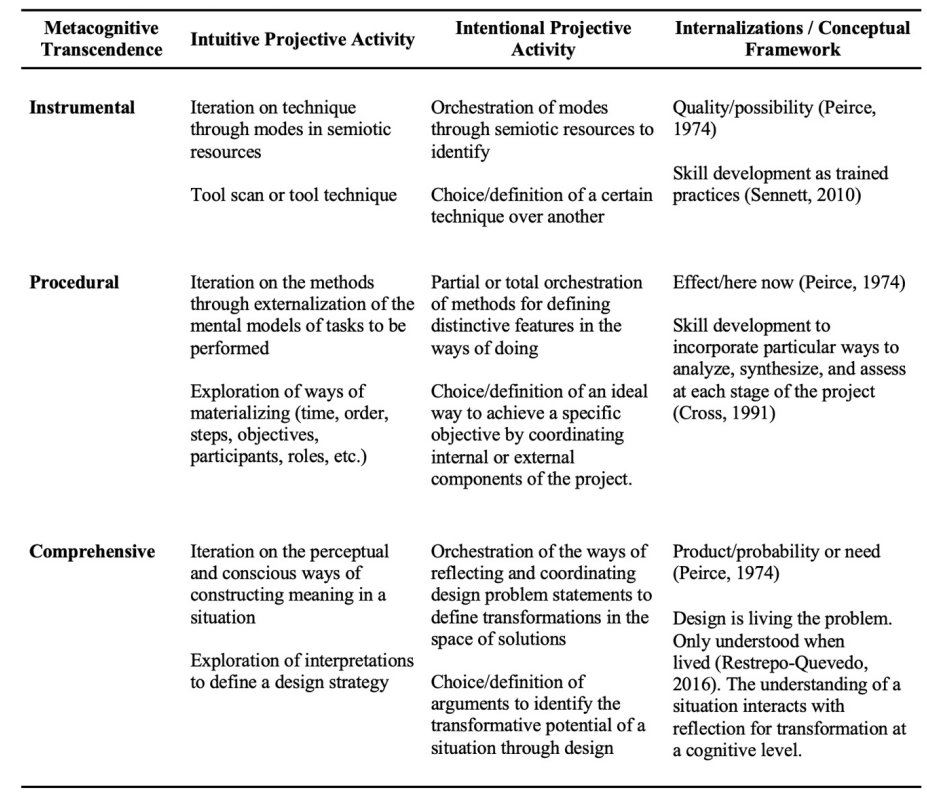

Note. Ways to transcend metacognitively. Characterization of the intuitive and intentional projective activity. Internalization in the student and conceptual framework.

Source: Own elaboration. 
Initially, as shown in Table 3, it is possible to understand that the parameters of transcendence for our findings are directly related to the ways of targeting the metacognitive effort of students. We present below three approaches identified through our study: instrumental metacognitive transcendence, procedural metacognitive transcendence, and comprehensive metacognitive transcendence.

It is noticeable that none of these three transcendence scenarios is more important than the other. Regarding an intentional cognitive/metacognitive process, the motivation of the students may range from the influence of teachers (Coll et al., 2009) to the need to complete a particular task.

We also recognize that the projective activity of design could not be completed comprehensively with only one of these transcendence scenarios. Therefore, the student can prioritize any of them based on their motivations, interests, and influences, highlighting their skills or abilities inherent to the disciplinary field in any of the cases explained below.

\subsection{Instrumental Metacognitive Transcendence}

From the disciplinary perspective of design, the ways of materializing require specific technical proficiency. Generally, design teaching and learning processes rely on the repetition of activities or technical purposes that focus on solving specific externalization under a commission or project. Thus, elements that have to do with the development of a technical domain are put into play to monitor, control, and supervise (Livingston, 2003) actions aimed at evaluating a materialization technique.

The design sketchbook reveals this process as continuous iteration on the tool and the technique itself; the effort focus of the student on identifying the ideal 
externalization tool for the expected result and how to use it for this purpose is evident.

This decision never starts from uncertainty; the student uses his or her knowledge and skills developed in any of the training stages and incorporates them as an integral part of the transition from IuA to leA. Therefore, the instrumental approach is constituted when the student focuses on using the tool and what he or she can achieve with it. This transcendence is then embodied in a mediation that characterizes suitable ways of externalizing, related to both the abilities and level of training of the student.

From Peirce's pragmatic perspective (1974), the meaning of an intellectual conception is determined by the practical consequences, related to the students' needs to externalize and iteratively test their abilities so that the ideal way to complete a task comes to them. The preceding is then associated with the idea of firstness expressed as spontaneity, originality, and pure freedom, as observed in the sketches of the sketchbooks. In all cases, it is associated with the concrete quality of the interim result, which is then reflected in the manner of carrying out the activity through the externalization technique that can be perceived by a third party.

This future possibility does not necessarily connect the $I u A$ with the result. Thus, a trial-error repertoire is structured to try to make sense of a technique on a specific plane as a projective action in the design exercise. The ability of a student to transcend is related to their interests and the stage of their training process; however, emerging motivational agents such as curiosity or standing out (Adar, 1969; Bacas \& Martín-Díaz, 1992) can take part in promoting reflective and control processes of the student when undertaking an instrumental metacognitive transcendence process. Finally, we note that the technique is trained and can become a continuous practice. Both the 
training process of the technique and the technical process itself are transferred to practice, which entails the transition to a technically intentional action to reduce the uncertainty when externalizing the proposal (Figure 2).

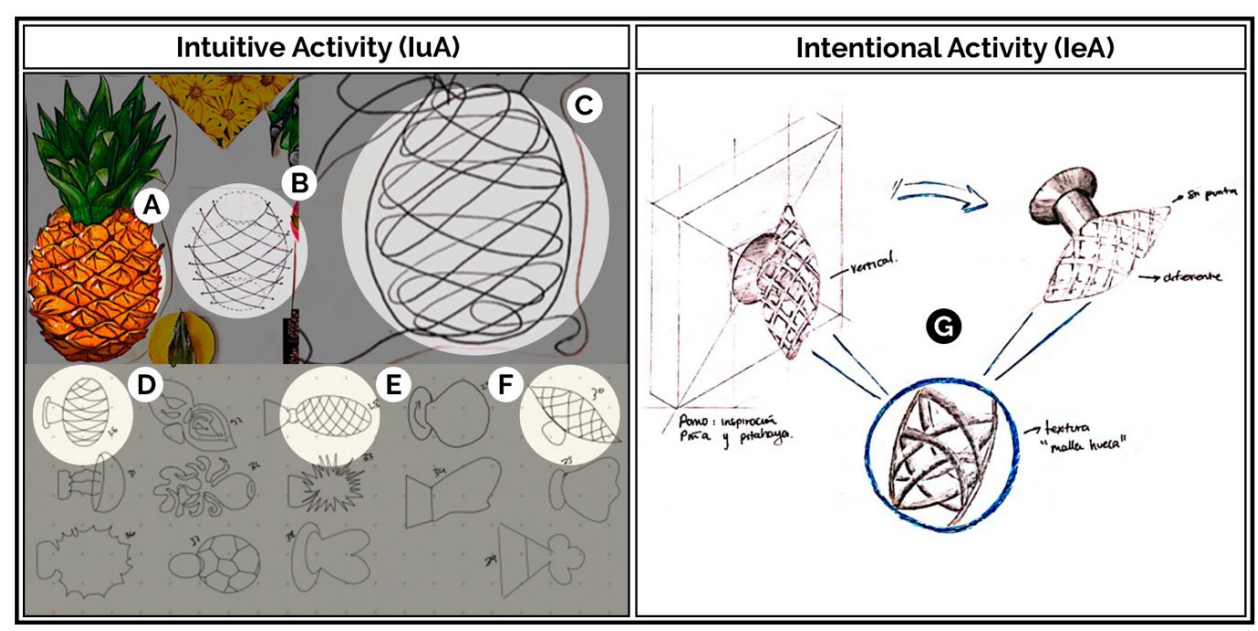

Figure 2. Instrumental Metacognitive Transcendence. Note. Left (Intuitive Activity): Exploratory sketches from experience, first externalizations. Right (Intentional Activity): Structured sketches in disciplinary languages. Source: Own elaboration based on extracts from industrial design sketchbooks analyzed in the research.

Figure 2 demonstrates how the student externalizes his or her instrumental metacognitive transcendence process, as the sketches of the intuitive activity look basic and taken from experience. The right side shows argued sketches with the techniques commonly used in the discipline, denoting greater regulation of their mental processes to communicate the attributes of their proposal. Specifically, Figure 2 section A provides an illustration technique that represents the pineapple figuratively and allows the student to analyze the fruit geometrically in search of a formal exploration, representing the 
compositional patterns and structures of the fruit (Figure 2, section B). Then, the student continues to explore these patterns and structures in the abstraction of Figure 2 section C. Figures 2 section D, 2 section $\mathrm{E}$, and 2 section $\mathrm{F}$ are basic sketches of application of the principles in Figures $2 \mathrm{~B}$ and $2 \mathrm{C}$, which transcend in Figure 2G when representing the proposal from codes and meanings having a representation system typical of industrial design, such as the isometric perspective. Finally, the student pays attention to constructive parameters: constructive lines in the drawing, the right angles according to each axonometry, different line intensities, magnifications as a lens to highlight details, and text to complement the argumentation of a proposal.

\subsection{Procedural Metacognitive Transcendence}

As the training process advances, the designer finds better and more adapted ways of constructing meanings by performing specific tasks throughout their process, which is made possible by accumulated experiences that provide the opportunity of characterizing the moments and strategies for achieving the proposed goals in each stage of the analysis. In addition, it is understood that there are ways of developing the proposals through unstructured parts that coordinate design with cognition (Cross, 2006), which are incorporated directly or implicitly in teaching processes. In other words, there may be an intention to explain a method to implement a specific projective activity or the explanation itself introduces a way of executing into the mental model of the student (Norman, 1983). In either case, the student transforms his mental model by identifying virtues, potentialities, or disadvantages in performing a task from design, known as the design method.

Authors such as Buchanan (1992) and Jones (2014) have identified the way of executing a design as the defined and intentional manner of a designer to accomplish a goal. From Buchanan's perspective (1992), it is the intention 
to develop a specific order depending on a design discipline or, from Jones' view (2014), it is a form of orienting the result according to a design problem statement. Whatever the case of study, the student makes iterative attempts to complete a task typical of the projective activity from the discipline or the transformation approach. In this study, we identified how this iteration gives the cognitive activity a metacognitive character; therefore, the performance of the task includes the question "how is the task performed?" to transcend the current level of the process.

According to this reflection, multiple attempts to carry out a projective activity at a stage of the process triggers two phenomena in the student: a) an orchestration of methods or parts of them and b) the identification of their components. The methods of the former are incorporated based on own experiences or conceptual models transmitted as segments of an explanation to recognize an ideal way of executing. The latter includes performance timelines, order of execution, sequence of steps, objectives of each step, and the participants, their skills, and roles. This reflection on the regulation of, control over, and proficiency in the order of execution is what we identify as a way of transcending metacognitively regarding procedures.

From pragmatism, this action constructs meanings from what Peirce (1974) calls secondness, explained as something that is here and now or the implication that the student builds. It intends to connect their purposes and ways of executing to transform them into particularity and promotes emergent forms of asking oneself about the ways of doing; therefore, the student is aware of other ways that emerge from the design problem statement, the design discipline to which the situation belongs, and the discipline's methodological tradition. However, for the student, his or her way of doing stands out, as identified through his or her procedural metacognitive transcendence (Figure 3). 


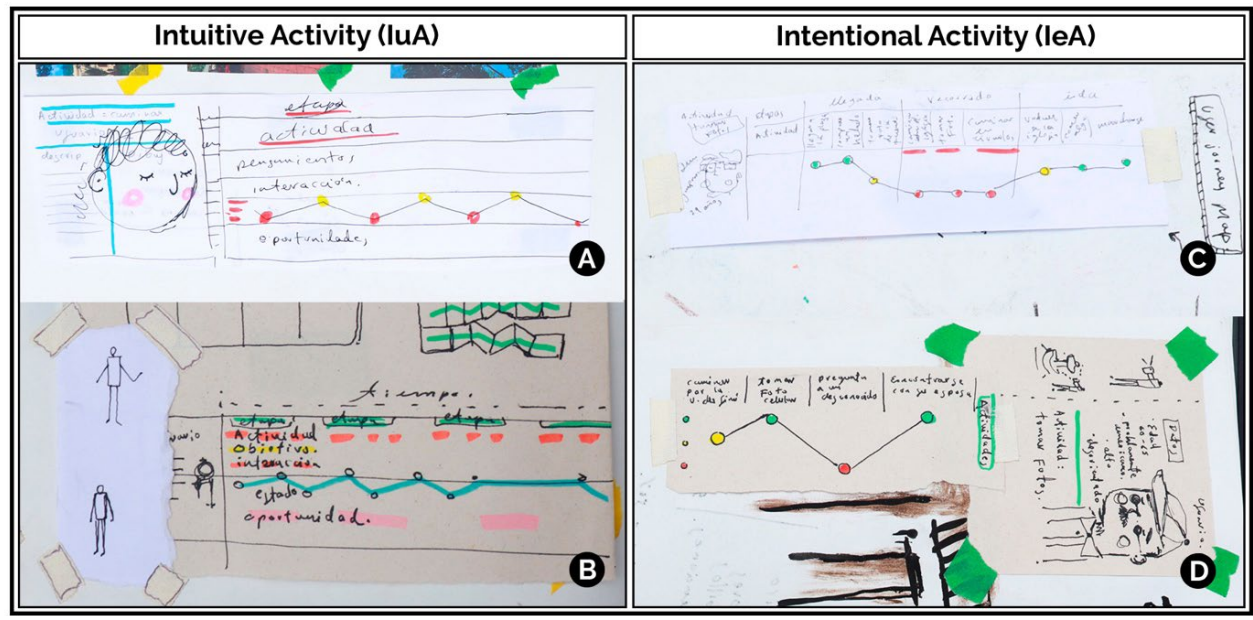

Figure 3. Procedural Metacognitive Transcendence. Note. Left (Intuitive Activity): Exploration of an application method, explanatory notes. Right (Intentional Activity): Implementation of the method to carry out activities in working space. Source: Own elaboration based on extracts from graphic design sketchbooks analyzed in the research.

Figure 3 shows how the student transcends metacognitively at the procedural level to the extent that he goes from the instruction given by the teacher to the internalization and appropriation of the method, as demonstrated by two qualitative aspects of the representations in this figure. Figure 3 section A shows something that, in Epstein's words (2010), could be called crudely integrated through faster processing and "oriented towards immediate action" (p. 299), where the student outlines rapidly and simply the main instructions of the procedure presented by the teacher. Figure 3B displays how the student makes his first attempts to use the method, trying to identify its function and the types of inputs to obtain. 
Figure 3C shows slower processing, allowing the student to internalize the instructions and create his analysis codes and representation resources. Finally, in Figure 3D, the student utilizes those resources required by the specificity of the case. Figures $3 \mathrm{~A}$ and $3 \mathrm{~B}$ provide more emotional representations, as far as the student constructs meaning for the author himself rather than generating a representation to communicate with others. In contrast, Figures 3C and 3D are perceived as rational externalizations that establish correlated, argued, and differentiated hierarchies, thus exceeding the initial instructions.

\subsection{Comprehensive Metacognitive Transcendence}

In design theory (Cross, 2011; Visser, 2006a), projects start their way from the so-called ill structured problems - those based on situations stated from a social dynamic — , which are projected in an expectation, opportunity, or need. To the extent that the student goes through different levels of experimental iteration, the relationship between the problem and the transformation/solution is integrated because the collected data and characteristics of the situation allow for an internalization that differs from the moment the project started.

It is common in this discipline for design processes to be introduced by a client or project brief (Ryd, 2004), giving solution or transforming ideas at a starting point. We could say that there are two types of brief or design instruction: declarative, informing the task to be performed or objective to be achieved, and exploratory, involving a design cognition process (Cross, 2006) that requires the analytical abilities of the student to project the expected solution or transformation.

However, students may not reach any results if they have not cognitively interacted with the information in the brief. The expectation is that students gain learning of the situation to decrease the level of uncertainty about the 
relevance of the solution. We call this living the problem (Restrepo-Quevedo, 2016), understanding that we can only grasp what we experience. In other words, only the designer can design, implying that projective actions in the disciplinary field make sense in the minds of the students when they are directly experienced by the doer, the apprentice of the projective activity.

These externalizations manifest themselves in modal forms that appear not to have a direct relationship with the projective activity but to increase the experience of the designer, promoting comprehensive metacognitive transcendence.

From Peirce's pragmatic perspective (1974), this action allows appreciating the thirdness, in which other ways of transcending interact and which is referred to as "what should be". Understanding must materialize in three central elements defined from the Peircian idea: mediation, transformation, and evolution or vital growth (p. 47). In design, the preceding is expressed in different dimensions of projective activity: mediation, such as the materiality of the solution, the identification of supports or substrates that define the symbolic materiality (Culache \& Obadă, 2014) of the representation, or prototyping status. Transformation can be recognized as the function (Qian \& Gero, 1996), that is, the actions for which it is being made and how it adapts to the operational standards of the solution statement. Finally, evolution or growth means the transformation or future perspective to fulfill the ultimate goal: to project.

Figure 4 shows a case of comprehensive metacognitive transcendence to the extent that the student goes from making visual or graphic representations of the idea in Figures 4A, 4B, and 4C. These representations allow intuiting general aspects of usability other than those represented in Figures $4 \mathrm{D}, 4 \mathrm{E}$, and $4 \mathrm{~F}$, resulting in the student experiencing the artifact mediated by the materialization of the testing model with which an intentional reflection can 
be made. Thus, he understands the concepts of product design physically, materially, and volumetrically, relating the temporal variable that use implies.

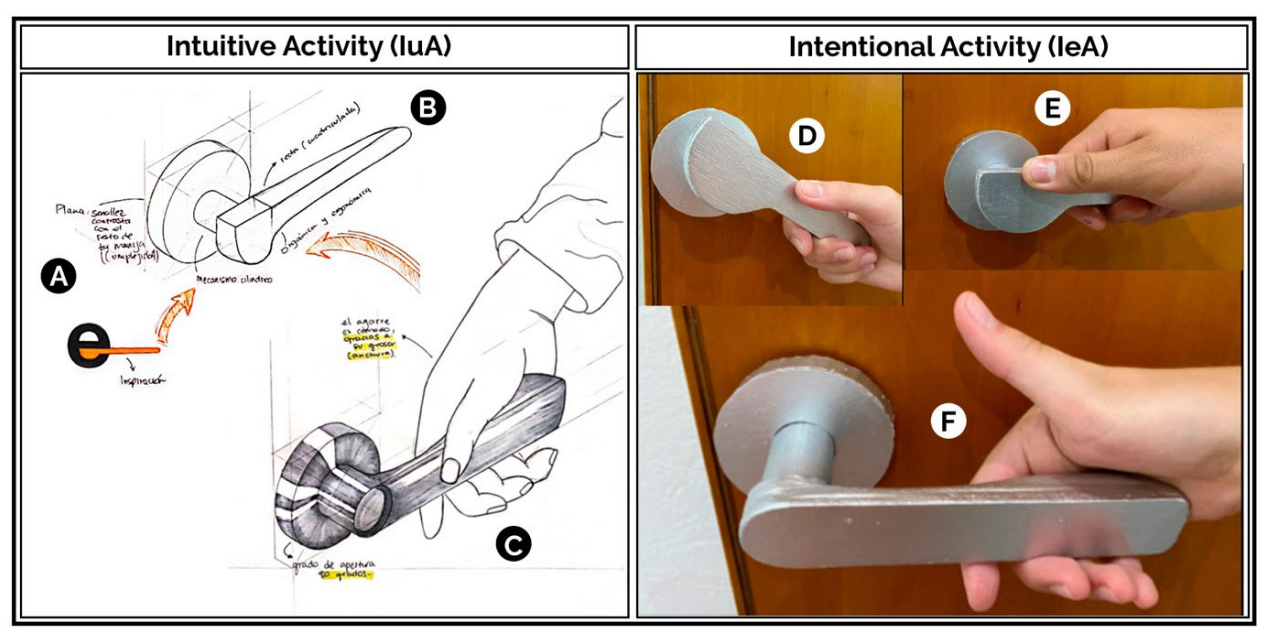

Figure 4. Comprehensive Metacognitive Transcendence. Note. Left (Intuitive Activity): Exploratory representational forms that define the modal forms adapted to the project's context of use. Right (Intentional Activity): Formalization of the prototype in the simulation of mediation, transformation, and evolution. Source: Own elaboration based on extracts from industrial design sketchbooks analyzed in the research.

Given that each external representation system has scopes and limits (Martí, 2003; Maya \& Patiño, 2020), the student transcends graphic limitations when making low- or mid-resolution prototypes, as shown in Figures 4 section $\mathrm{D}, 4 \mathrm{E}$, and $4 \mathrm{~F}$, to experience the idea in the fundamental space-time dimensions in order to apply product testing protocols.

In summary, we propose the idea of instrumental, procedural, and comprehensive metacognitive transcendence in learning design based on the evidence found in the sketchbook. It specifically describes the phenomenon of metacognition 
that usually occurs in projective activity as a strategy for regulating cognitive processes to transform an intuitive action into an intentional one mediated by the design sketchbook as a cognitive artifact (González-Tobón et al., 2020), where visual and linguistic modes externalize students' ideas.

\section{Conclusions}

The phenomenographic approach facilitates the study of the intentional interaction between the control and regulation of cognitive processes required by students for learning projective activity. This phenomenon can be verified through the sample of industrial and graphic design sketchbooks, which recorded externalizations using visual modes that account for the mental models reported by students during their training process.

Through the metacognition analysis of projective activity in design, we recognized three stages of metacognitive transcendence:

1. Instrumental, related to the development of a technical proficiency in the discipline that promotes monitoring, control, and supervision of the cognitive resources required to assess the ideal technique for materializing visual records.

2. Procedural, focused on the intention to explain an execution method, noted in the logical sequence proposed by the student to accounts for their specific projective activity.

3. Comprehensive, in which students can only reach a project proposal when they have experienced the problem, allowing them to intentionally put forward a transformation strategy mediated by projective activity.

Based on the evidence, we can affirm that any of the three described and characterized scenarios can occur independently of the other two; that is, there 
is no targeting order. However, it can be inferred that they occur according to the interests of students in the projective activity. The findings demonstrate that the construction of meaning tends to realize in the projective activity when the student develops instrumental, procedural, and comprehensive metacognitive transcendence in their cognitive processes, which are intentionally proposed as project objectives.

By analyzing the design sketchbooks, we could prove the importance of facilitating metacognitive processes of students to motivate metacognitive transcendence mediated by reflection, regulation, and control, thus enhancing projective activity. We also identified the significance for design teaching of guaranteeing teaching strategies that include these transcendences in projective activity, aligned with methods and didactics.

The metacognitive focus on these transcendences constitutes a new intuitive process integrated into the student that provides him or her with the ability to consolidate knowledge through the experience reflected in the ways of doing. This scenario occurs cyclically and promotes the transition from intuitive to intentional in the projective activity, transmitted to the student in their training process.

\section{References}

Ackerman, R. \& Thompson, V. (2017). Meta-reasoning: Monitoring and control of thinking and reasoning. Trends in Cognitive Sciences, 21(8), 607-617.

https://doi-org/10.1016/j.tics.2017.05.004

Adar, L. (1969). A Theoretical Framework for the Study of Motivation in Education. Hebrew University.

Anstey, M. \& Bull, G. (2010). Helping teachers to explore multimodal texts. Curriculum \& Leadership Journal, 8(16). http://goo.gl/Na2JR 
Bacas, P. \& Martín-Díaz, M. J. (1992). Distintas Motivaciones para Aprender Ciencias (Ciencias de la Naturaleza). Narcea.

Ball, L. J. \& Christensen, B. T. (2019). Advancing an understanding of design cognition and design metacognition: Progress and prospects. Design Studies, 65, 35-59. https://doi. org/10.1016/j.destud.2019.10.003

Brown, T. \& Martin, R. (2015). Design for action: How to use design thinking to make great things actually happen. Harvard Business Review, 56-64. https://hbr.org/2015/09/designfor-action

Buchanan, R. (1992). Wicked Problems in Design Thinking. Design Issues, 8(2), 5-21. https:// doi.org/10.2307/1511637

Burnette, C. (1 nov 2009). A theory of design thinking. FAIA Prepared in response to the Torquay Conference on Design Thinking [conference]. Swinburne University of Technology, Melbourne, Australia.

Carlson, S. E., Rees, D. G., Maliakal, L. V., Gerber, E. M. \& Easterday, M. W. (2020). The design risks framework: Understanding metacognition for iteration. Design Studies, 70, 100961. https://doi.org/10.1016/j.destud.2020.100961

Coll, C., Engel, A. \& Bustos, A. (2009). Distributed Teaching Presence and Participants' Activity Profiles: a theoretical approach to the structural analysis of Asynchronous Learning Networks. European Journal of Education, 44(4), 521-538. https://doi.org/10.1111/j.14653435.2009.01406.x

Cross, N. (1991). Engineering Design Methods: Strategies for Product Design. John Wiley \& Sons.

Cross, N. (2001). Designerly Ways of Knowing: Design Discipline versus Design Science. Design Issues, 17(3), 49-55. https://doi.org/10.1162/074793601750357196

Cross, N. (2006). Designerly Ways of Knowing. Springer-Verlag London Limited.

Cross, N. (2011). Design thinking : Understanding How Designers Think and Work. Berg.

Culache, O. \& Obadă, D. R. (2014). Multimodality as a Premise for Inducing Online Flow on a Brand Website: A Social Semiotic Approach. Procedia - Social and Behavioral Sciences, 149, 261-268. https://doi.org/10.1016/j.sbspro.2014.08.227

Dorst, K. (2011). The core of 'design thinking'and its application. Design Studies, 32(6), 521532. https://doi.org/10.1016/j.destud.2011.07.006 
Epstein, S. (2010). Demystifying intuition: What it is, what it does, and how it does it. Psychological Inquiry, 21(4), 295-312. https://doi.org/10.1080/1047840X.2010.523875

Flavell, J. H. (1976). Metacognitive aspects of problem solving. In L. B. Resnick (Ed.), The nature of intelligence (pp. 231-235). Hillsdale, NJ: Lawrence Erlbaum.

Flavell, J. H. (1979). Metacognition and cognitive monitoring: A new area of cognitivedevelopmental inquiry. American Psychologist, 34(10), 906-911. https://psycnet.apa.org/ doi/10.1037/0003-066X.34.10.906

González-Tobón, J., Cuervo, R., Hernández, E. \& Camacho, J. (2020). The logbook in design, learning cognitive artifact. Externalization of mental models and metacognition. Bitácora Urbano Territorial, 30(2), 151-162. https://doi.org/10.15446/bitacora.v30n2.81635

González-Ugalde, C. (2014). Investigación fenomenográfica. Magis, 7(14), 141-158. https:// www.redalyc.org/articulo.oa?id=281032883011

Griffin, T. D., Wiley, J. \& Salas, C. R. (2013). Supporting effective self-regulated learning: The critical role of monitoring. In International handbook of metacognition and learning technologies (pp. 19-34). Springer. http://dx.doi.org/10.1007/978-1-4419-5546-3_2

Holroyd, A. (2009). Interpretive hermeneutics and modifying the modern idea of method. The Canadian Journal of Nursing Research, 40(4), 130-145. https://pubmed.ncbi.nlm.nih. gov/19186789/

Jewitt, C. (Ed.). (2011). The Routledge Handbook of Multimodal Analysis. Routledge.

Johnson-Laird, P. N. (1980). Mental Models in Cognitive Science. Cognitive Science, 4(1), 71115. https://doi.org/10.1207/s15516709cog0401_4

Jones, P. (2014). Systemic design principles for complex social systems. In G.S. Metcalf (Ed.) Social systems and design, vol.1,(pp.91-128). https://doi.org/10.1007/978-4-431-54478-4

Kavousi, S., Miller, P. A. \& Alexander, P. A. (2020). Modeling metacognition in design thinking and design making. International Journal of Technology and Design Education, 30(4), 709735. https://doi.org/10.1007/s10798-019-09521-9

Krippendorff, K. (2007). An exploration of artificiality. Artifact, 1(1), 17-22. https://repository. upenn.edu/asc_papers/238/

Livingston, J. A. (2003). Metacognition: An Overview. 
Martí, E. (2003). Representar el Mundo Externamente. La Adquisición Infantil de los Sistemas Externos de Representación. A. Machado Libros S.A.

Marton, F. (1986). Phenomenography-a research approach to investigating different understandings of reality. Journal of Thought, 28-49. https://www.jstor.org/stable/42589189

Maya, J. \& Patiño, E. (2020). Propiedades de las representaciones en diseño: una exploración interdisciplinaria de su rol funcional. Kepes, 17(21), 17-60. https://doi.org/10.17151/ kepes.2020.17.21.2

Mayer, R. (1998). Cognitive, metacognitive, and motivational aspects of problem solving. Instructional Science, 26(1-2), 49-63.

Norman, D. (1983). Some observations on mental models. Mental Models, 7(112), 7-14.

Norman, D. (1991). Cognitive artifacts. In J.M. Carroll (Ed.). Designing Interaction: Psychology at the Human-Computer Interface (pp. 17-38) Cambridge University Press.

Peirce, C. S. (1974). Collected papers of Charles Sanders Peirce (Vol. 2). Harvard University Press.

Powers, M. (2016). Self-Regulated Design Learning: A Foundation and Framework for Teaching and Learning Design. Routledge. https://doi.org/10.4324/9781315746081

Qian, L. \& Gero, J. S. (1996). Function-behavior-structure paths and their role in analogy-based design. Artificial Intelligence for Engeneering Design, Analysis Ans Manufacturing, 10(4), 289-312. https://doi.org/10.1017/S0890060400001633

Ramírez Escobar, M. F. (2020). Prácticas de visualización en la investigación académica en diseño gráfico. Kepes, 17(22), 76-108. https://doi.org/10.17151/kepes.2020.17.22.4

Restrepo-Quevedo, D. A. (Dec. 2015). Developing a Reference Framework for the Research of Multimodality in Design. In. University of Caldas (Ed.) Primer Precoloquio Doctoral: Memorias Doctorado en Diseño y Creación (pp.104-108). https://bit.ly/2w9QY9O

Restrepo-Quevedo, D. A. (2016). Intercreativity in Potency: Designing of Virtual Learning Environments Enhancers of Creative Participations (Intercreatividad en Potencia: Diseño de Ambientes Virtuales de Aprendizaje Potenciadores de Participaciones Creativas) [Doctoral dissertation, Universidad de Caldas]. https://doi.org/10.13140/RG.2.2.14010.70085

Rittel, H. \& Webber, M. (1973). Dilemmas in a general theory of planning. Policy Sciences, 4(2), $155-169$. 
Ryd, N. (2004). The design brief as carrier of client information during the construction process. Design Studies, 25(3), 231-249.

https://doi.org. /10.1016/j.destud.2003.10.003

Sennett, R (2010). El Artesano. Editorial Anagrama.

Simon, H. (1973). The structure of ill structured problems. Artificial Intelligence, 4, 181-201. https://doi.org/10.1016/0004-3702(73)90011-8

Simon, H. (1996). The Sciences of the Artificial.

Smith, T. W., \& Colby, S. A. (2007). Teaching for Deep Learning. The Clearing House: A Journal of Educational Strategies, Issues and Ideas, 80(5), 205-210. https://doi.org/10.3200/ tchs.80.5.205-210

Tamayo, O.E. (2006). La metacognición en los modelos para la enseñanza y el aprendizaje de las ciencias. In VV. AA., Los Bordes de La Pedagogía: Del Modelo a La Ruptura (pp. 275-306). Universidad Pedagógica Nacional.

Tight, M. (2016). Phenomenography: the development and application of an innovative research design in higher education research. International Journal of Social Research Methodology, 19(3), 319-338. http://10.0.4.56/13645579.2015.1010284

Visser, W. (2006a). Designing as Construction of Representations: A Dynamic Viewpoint in Cognitive Design Research. Human-Computer Interaction, 21(1), 103-152. https://doi. org/10.1207/s15327051hci2101_4

Visser, W. (2006b). The Cognitive Artifacts of Designing. Lawrence Erlbaum Associates, Inc.

Yzerbyt, V., Lories, G. \& Dardenne, B. (1998). Metacognition: Cognitive and Social Dimensions. SAGE Publications Ltd.

How to cite: Restrepo-Quevedo, D. A., González-Tobón, J., Cuervo, R., Camacho, J., \& HernándezMihajlovic, E. (2022). Metacognitive Transcendence in the Learning of the Project Activity of Design through the Sketchbook Visuality. Revista KEPES, 19(25), 295-324. https://doi.org/10.17151/kepes.2022.19.25.11 